\section{Reported healthcare workers knowledge and practices of hand hygiene in specialist hospitals of Kano, Northwest Nigeria}

\author{
Auwal Umar Gajida, ${ }^{1}$ \\ Usman Muhammad Ibrahim, ${ }^{2}$ \\ Rabiu Ibrahim Jalo, ${ }^{1}$ Musa Muhammad \\ Bello, ${ }^{1}$ Amole Taiwo Gboluwaga, ${ }^{1}$ \\ Dalha Halliru Gwarzo, ${ }^{3}$ Fatima Hassan \\ Hanga, ${ }^{4}$ Umar Bello, ${ }^{5}$ Abba Ahmed \\ Danzomo, ${ }^{6}$ Muhammad Sani Aliyu, ${ }^{7}$
}

Aisha Aliyu Abulfathi, ${ }^{2}$ Nafisat Tijjani

Abdullahi ${ }^{2}$

${ }^{1}$ Department of Community Medicine,

Bayero University and Aminu Kano

Teaching Hospital, Kano State;

${ }^{2}$ Department of Community Medicine,

Aminu Kano Teaching Hospital, Kano,

State; ${ }^{3}$ Department of Haematology,

Bayero University, Kano State;

${ }^{4}$ Department of Paediatrics, Bayero

University, Kano State; ${ }^{5}$ Ministry of

Health, Katsina, Katsina State; ${ }^{6}$ World

Health Organization, Jigawa State Field

Office; ${ }^{7}$ Department of Microbiology,

Ahmadu Bello University Zaria, Kaduna

State, Nigeria

\begin{abstract}
Compliance with recommended hand hygiene among healthcare providers is important in the prevention of morbidity and mortality associated with hospitalacquired infections including drug resistant microorganisms. This study aimed to determine the reported knowledge and hand hygiene practices among healthcare workers in Specialist Hospitals in Kano, Nigeria. Descriptive cross-sectional study design was used to study 302 healthcare workers in the specialist hospitals in Kano. Data was collected using semi-structured self-administered questionnaire and analyzed at univariate, bivariate and multivariate levels using IBM SPSS version 22. The age of the respondents ranged from 18 to 59 years with a mean of $31.4 \pm 9$ years. Up to onethird $(36.1 \%)$ of the respondents had poor knowledge despite the reported hand hygiene practice of $78 \%$. Use of Alcohol Based Hand Rub and soap and water constituted $26.7 \%$ and $15.7 \%$ respectively. There was statistically significant association between working in MMSH, working in Pediatrics wards, CHEW cadre, and attendance of hand hygiene training in the last 3
\end{abstract}

years and having good knowledge of hand hygiene. Hand hygiene training was found to improve hand hygiene knowledge $[\mathrm{AOR}=1.58,95 \% \mathrm{CI}=(1.01-2.5)]$ and practice $[\mathrm{AOR}=1.12 \quad 95 \% \mathrm{CI}=(0.64-1.99)]$. Reported knowledge of hand hygiene was poor but the practices were encouraging and associated with formal training of healthcare workers on hand hygiene. Therefore, Hospital management should ensure regular hand hygiene training and re-training among healthcare workers.

\section{Introduction}

Every year millions of patients globally are affected by infections that are transmitted in healthcare settings. ${ }^{1-3}$ Most of these infections can be prevented through a simple precautionary measure of proper hand hygiene. Unfortunately, compliance with hand hygiene guidelines provided by World Health Organization (WHO) is usually poor among healthcare workers, and materials needed for hand hygiene are not readily available. ${ }^{1-3}$

Health care-associated infections occur worldwide and affect both developed and resource-poor countries. ${ }^{1-4}$ Infections acquired in health-care settings are among the major causes of death and increased morbidity in hospitalized patients. ${ }^{1-6}$ They represent a significant burden for both the patient, healthcare providers, families and public health. Health care-associated infections rank as major killers of patients of all ages, particularly among the most vulnerable members of the population. According to a recent European multicenter study, the proportion of infected patients in the Intensive Care Units (ICU) can be as high as $51 \%$ and most of these are health careassociated. ${ }^{1-7}$

It was estimated that at any point in time, more than 1.4 million people worldwide suffer from infections acquired in hospitals. ${ }^{2,4}$ In developed countries, between $5 \%$ and $10 \%$ of patients acquire one or more infections and $15 \%-40 \%$ of patients admitted to critical care are thought to be affected. In resource-poor settings, rates of infection can exceed $20 \%$, but available data are scanty in developing and transitional countries. ${ }^{2,4}$

Barriers resulting to poor compliance with recommended hand hygiene practices may be organizational, related to the individual healthcare worker or to patient safety issue $^{1-8}$ Organizational barriers, such as a lack of accessibility, inadequate maintenance of hand hygiene facilities and poor access to hand hygiene products, overcrowding and understaffing, and lack of role model negatively affect compliance with recommended
Correspondence: Usman Muhammad Ibrahim, Department of Community Medicine, Aminu Kano Teaching Hospital, Kano, Nigeria.

Tel.: +2348032112497

E-mail: usmanmi2000@gmail.com

Key words: Knowledge; practices; hand hygiene; healthcare workers; Kano.

Contributions: All authors contributed equally Conflict of interest: The authors declare no conflict of interest

Availability of data and materials: The datasets used and/or analyzed during the current study are available from the corresponding author on reasonable request

Ethics approval and consent to participate: Ethical approval was obtained from Health Research Ethics Committee of Kano State Ministry of Health with approval number of $\mathrm{MOH} / \mathrm{OFF} / 797 / \mathrm{TI} / 731$. Advocacy visit was conducted to the heads of the selected units. Data was collected from May 2018 to August 2018. All the principles of research ethics were respected throughout the study and respondents indicated acceptance by filling and signing the consent form.

Consent for publication: Not applicable

Received for publication: 7 February 2020.

Revision received: 21 December 2020.

Accepted for publication: 21 December 2020.

This work is licensed under a Creative Commons Attribution NonCommercial 4.0 License (CC BY-NC 4.0).

C Copyright: the Author(s), 2020

Licensee PAGEPress, Italy

Pyramid Journal of Medicine 2020; 3:78 doi:10.4081/pjm.2020.78

hand hygiene practice. ${ }^{1-5}$ Individual barriers to hand hygiene practices may include the misconception that hand hygiene is not necessary when gloves are worn, skepticism about the value of hand hygiene when the hands are not visibly soiled, lack of peer pressure to perform hand hygiene, lack of time to perform hand washing, poor understanding of the clear association between healthcare-associated microorganisms on the hands of healthcare workers and Hospital acquired infections, and lack of understanding of how effective hand hygiene, when indicated, reduces the crosstransmission of microorganisms. ${ }^{1-8}$ There is paucity of data on healthcare workers hand hygiene knowledge and practices especially in Northwestern Nigeria and data obtained can be used by policy makers in addressing the identified barriers. 


\section{Materials and Methods}

\section{Study area}

Murtala Muhammad Specialist Hospital (MMSH) is located within the ancient city walls of Kano. The Hospital was established in 1927, initially called City Hospital with a capacity of 16 beds at that time. It was renamed after the former Nigerian Head of State, General Murtala Ramat Muhammad, in 1976. It became a Specialist Hospital in 1987 and is located eastward $400 \mathrm{~m}$ away from Kofar Mata and westward about $700 \mathrm{~m}$ from the emir's palace. Hasiya Bayero Paediatrics Hospital (HBPH) is a Paediatrics Specialist Hospital that was established in 1990 and was named after the mother of late Emir of Kano State Dr (Alh) Ado Bayero. The hospital has both inpatients and out-patients services, including laboratory services.

There is high patients turn over in the two facilities far exceeding the required healthcare providers to patient ratio. This is partly because MMSH and HBPH serve as a referral center not only for the state but also for some parts of Northern Nigeria and neighboring Niger republic. The State Government is responsible for maintaining the two hospitals including recruitment and training of healthcare workers on infection prevention and control, supervision and also ensuring the supplies of all the logistics needed.

\section{Study design}

A cross sectional descriptive study was used.

\section{Study population}

The study population included all the health care workers in MMSH and $\mathrm{HBPH}$ involved in the care of in-patients. Staff on annual and maternity leave who did not return to work throughout the period of data collection were excluded from the study.

\section{Sample size estimation}

Sample of 334 was determined using Fisher's formula for estimating minimum sample size for descriptive studies. ${ }^{8}$ Standard normal deviate (z) 1.96 at $95 \%$ confidence interval and margin of error (d) 0.05 and prevalence (p) from previous study, ${ }^{9}$ point prevalence rate $(25.7 \%)$ obtained from a past study and a nonresponse rate of $14 \%$ was used to compute the sample size. ${ }^{10}$

\section{Sampling technique}

Three staged sampling technique was used for the selection of respondents in 2 out of 8 specialist hospitals within Kano metropolis. In the first stage, the list of all the Specialist Hospitals in the Metropolis was obtained from Kano Hospital Management Board from which MMSH and $\mathrm{HBPH}$ were selected by simple random sampling technique using balloting. In the second stage, the list of all the clinical departments was obtained from the hospital authorities and 4 out of 16 departments were selected by simple random sampling technique using balloting. In the third stage, the list of healthcare workers in the selected departments were obtained from the respective heads of departments, and respondents were proportionately allocated based on the number of healthcare workers and cadre in each of the selected departments.

\section{Instrument for data collection}

The instrument used was adapted semi structured pre-tested self-administered questionnaire. ${ }^{11-16}$ The questionnaire consisted of three sections: section A sought the sociodemographic characteristics of the respondents, section $\mathrm{B}$ explored the knowledge of the respondents on hand hygiene while section $\mathrm{C}$ asked questions on hand hygiene practices among the respondent and the barriers to hand hygiene practices. The questionnaire was pretested in another hospital far away from the selected hospitals. Respondents were informed about the importance of filling the questionnaire completely and not checking up answers at home.

\section{Data management and analysis}

Data was analyzed using IBM SPSS Statistics for Windows, Version 22. Quantitative variables were summarized using appropriate measures of central tendency and dispersion while categorical variables were presented as frequencies and percentages. The dependent/outcome variables were knowledge of hand hygiene and hand hygiene practices while the independent variables were age, highest educational status, tribe, marital status, among others.

\section{Knowledge items}

There were 25 Questions that assessed knowledge of hand hygiene among the respondents; any respondent who correctly responded to question was given one point, while zero point was allocated for wrong response. Proportions obtained were classified as follows: Good knowledge for those with greater than or equal to $75 \%$, fair knowledge for those with greater than $50 \%$ but less than $75 \%$ and poor knowledge for those with less than $50 \%{ }^{16}$

\section{Practice items}

There were 12 questions with multiple responses that assessed practice of hand hygiene among the respondents, any respondent who correctly responded to question was given one point and zero point was allocated for wrong response. Hand hygiene practice was then scored based on points scored by individual respondents. Descriptive statistics was obtained for total hand hygiene practice scored by all the respondents and also for each professional category. Correct hand hygiene practice was considered for those with $50 \%$ and above, while wrong hand hygiene practice for those with below $50 \%{ }^{16}$

Chi square test was used to test for significant association between categorical variables and compared proportions in two or more groups. Logistic regression was used to adjust for confounders. A p-value of $\leq 0.05$ was considered statistically significant. All the variables with a $\mathrm{p} \leq 0.1$ at bivariate analysis were included in the logistic regression model to control for confounding. Adjusted Odds Ratio with 95\% confidence interval was used to determine the strength of association.

\section{Ethical considerations}

Ethical approval was obtained from Health Research Ethics Committee of Kano State Ministry of Health with approval number of $\mathrm{MOH} / \mathrm{OFF} / 797 / \mathrm{TI} / 731$. Advocacy visit was conducted to the heads of the selected units. Data was collected from May 2018 to August 2018. All the principles of research ethics were respected throughout the study and respondents indicated acceptance by filling and signing the consent form.

\section{Results}

Of the 334 questionnaires administered, only 302 were retrieved giving a response rate of $90.4 \%$.

\section{Socio-demographic characteristics of the respondents}

The age of the respondents ranged from 18 years to 59 years with a mean of $31.4 \pm 9$ years and more than half $159(52.7 \%)$ of them were between the ages of 21-30 years. More than three quarter $253(83.8 \%)$ of the respondents were from Murtala Muhammad Specialist Hospital, with the remaining 49 (16.2\%) from Hasiya Bayero Pediatrics Hospital. Females constituted majority $(186,61.6 \%)$ of the respondents. Almost half $(150,49.7 \%)$ of the respondents were employed within the last five years, the duration of employment ranged from 1-35 years with a median of 6 years. Forty percent (122) of respondents were nurses/midwives and almost a third $(87,29 \%)$ were doctors. The majority $(113,37.4 \%)$ of the 
respondents were from surgical wards, while Obstetrics and Gynecology ward had the lowest number of respondents (37, $12.3 \%$ ). Slightly more than half of the respondents $(156,51.7 \%)$ received training on hand hygiene in the last three years as shown in Table 1 below.

\section{Healthcare worker's knowledge of hand hygiene}

The minimum score for knowledge of hand hygiene was 3 and the maximum was 21 , with a mean score of $13.4 \pm 4.1$. About two-third $109(36.1 \%)$ of the respondents had good knowledge of hand hygiene as shown in Figure 1 below. The majority of the respondents $(233,77.2 \%)$ reported that hand hygiene should be observed before touching a patient and up to 217 (71.9\%) correctly responded that hand hygiene after touching a patient can prevent hospital acquired infections as shown in Table 2 below. More than two-thirds (233, 77.2\%) of the respondents correctly responded to the question on the role of hand hygiene before touching a patient in preventing infection transmission. However, most of the respondents wrongly answered the question $(225,74.5 \%)$ about the time needed for alcohol based hand rub to kill germs when used for hand hygiene.

\section{Healthcare worker's practice of hand hygiene}

The minimum score for practice of hand hygiene was 0 and the maximum was 9 , with a mean score of $5.6 \pm 1.7$. The majority of the respondents $(236,78.0 \%)$ had correct hand hygiene practice as shown in Figure 1 below. Similarly, up to $(252,83.4 \%)$ reported adhering to recommended hand hygiene practices as shown in Table 3 below.
Shortage of water was reported as a barrier to hand hygiene by $169(56.0 \%)$ as shown in Table 4 below.

Male healthcare workers were $40 \%$ more likely to have good hand hygiene practice $\{\mathrm{AOR}=0.4,95 \% \mathrm{CI}=(0.2-0.7)\}$ compared to their female counterparts. Likewise, hospital staff who were less than 30 years of age were $70 \%$ more likely to have good hand hygiene practice than older

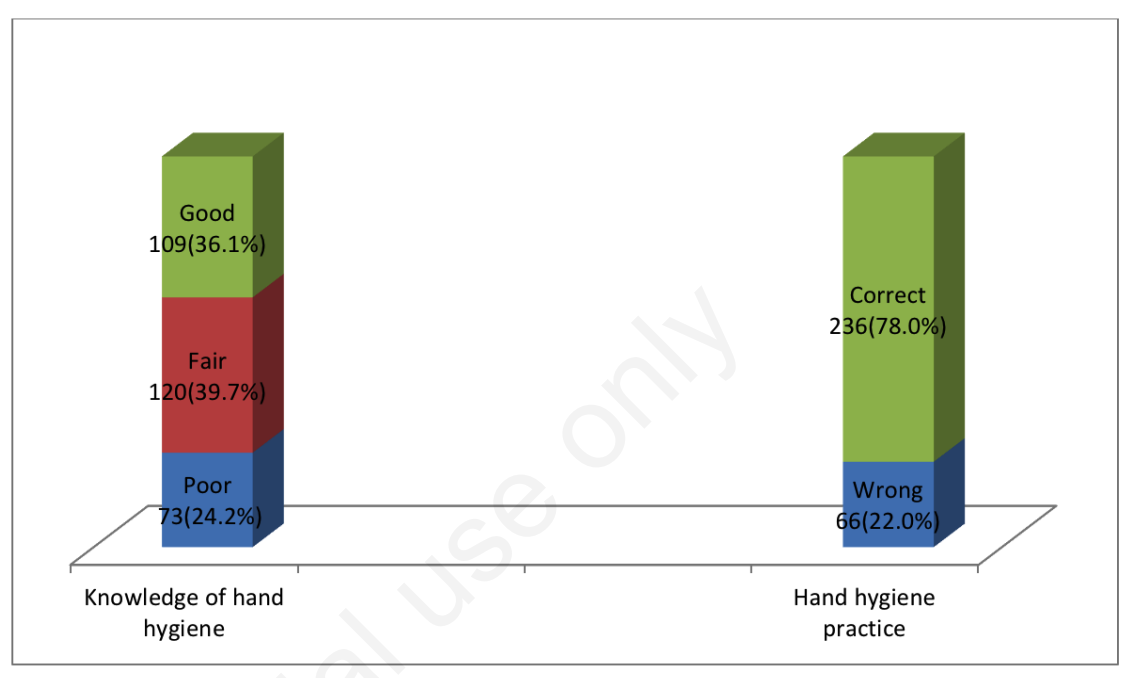

Figure 1. Distribution of hand hygiene knowledge and practices among respondent.

Table 1. Socio-demographic characteristics of respondents.

\begin{tabular}{|c|c|c|c|}
\hline Socio-demographic & Characteristics & Frequency n=302 & Percentage (\%) \\
\hline Age group (years) & $\begin{array}{l}18-20 \\
21-30 \\
31-40 \\
41-50 \\
51-60 \\
\text { Mean } \pm \text { SD }\end{array}$ & $\begin{array}{c}19 \\
159 \\
76 \\
42 \\
6 \\
31.4 \pm 9\end{array}$ & $\begin{array}{c}6.3 \\
52.7 \\
25.2 \\
13.8 \\
2.0\end{array}$ \\
\hline Sex & $\begin{array}{l}\text { Male } \\
\text { Female }\end{array}$ & $\begin{array}{l}116 \\
185\end{array}$ & $\begin{array}{l}38.0 \\
62.0\end{array}$ \\
\hline Professional Cadre & $\begin{array}{l}\text { Doctors } \\
\text { Nurses/midwives } \\
\text { Community Health Extension Workers } \\
\text { Attendants } \\
\text { Clinical assistants }\end{array}$ & $\begin{array}{c}87 \\
122 \\
46 \\
17 \\
30\end{array}$ & $\begin{array}{c}29.0 \\
40.0 \\
15.0 \\
6.0 \\
10.0\end{array}$ \\
\hline Duration in employment (years) & $\begin{array}{l}1-5 \\
6-10 \\
11-15 \\
16-20 \\
21-25 \\
26-30 \\
31-35 \\
\text { Range and Median }\end{array}$ & $\begin{array}{c}150 \\
72 \\
25 \\
21 \\
12 \\
16 \\
6 \\
1-35,6\end{array}$ & $\begin{array}{c}49.7 \\
23.8 \\
8.3 \\
7.0 \\
4.0 \\
5.2 \\
2.0\end{array}$ \\
\hline Department/Ward & $\begin{array}{l}\text { Medical } \\
\text { Paediatrics } \\
\text { Surgical } \\
\text { Obstetrics\& Gynaecology }\end{array}$ & $\begin{array}{c}51 \\
101 \\
113 \\
37\end{array}$ & $\begin{array}{l}16.9 \\
33.4 \\
37.4 \\
12.3\end{array}$ \\
\hline Hand hygiene training in the last 3 years & $\begin{array}{l}\text { Yes } \\
\text { No }\end{array}$ & $\begin{array}{l}156 \\
146\end{array}$ & $\begin{array}{l}52.0 \\
48.0\end{array}$ \\
\hline
\end{tabular}


healthcare workers $\quad\{\mathrm{AOR}=0.7, \quad 95 \%$ $\mathrm{CI}=(0.4-1.2)\}$. In addition, doctors were $90 \%$ more likely to have good hand hygiene practice than other healthcare providers in the hospital $\{\mathrm{AOR}=0.9,95 \% \mathrm{CI}=(0.6-1.3)\}$. Healthcare workers with good knowledge of hand hygiene were $30 \%$ more likely to have good hand hygiene practice $\{\mathrm{AOR}=1.3,95 \% \mathrm{CI}=(0.9-1.9)\}$, as shown in Table 5 and 6 below.

\section{Discussion}

About two-fifth (39.7\%) of the respondents had fair knowledge of hand hygiene with more than a third (36.1\%) having good knowledge and about a quarter $(24.2 \%)$ having poor knowledge. This was lower than the figures of $83 \%, 79 \%$ and $91.7 \%$ for good, fair and poor knowledge respectively, reported in previous studies. ${ }^{13,14}$ The difference may be due to availability of hand hygiene consumables that can promote improved knowledge of the indications and conditions appropriate for hand hygiene. The finding was however higher than the level of hand hygiene knowledge found in a study conducted in India, which reported $16.5 \%$ respondents to have good knowledge, ${ }^{15}$ which may be linked with previous training that was reported to be conducted in the study hospitals of this study. Healthcare workers with good knowledge of hand hygiene in this study were $30 \%$ more likely to practice good hand hygiene,

Table 2. Respondents correct responses to knowledge items.

\begin{tabular}{|c|c|}
\hline Knowledge items & Frequency $(\%) \mathrm{n}=302$ \\
\hline Main route of cross contamination & $235(55.8)$ \\
\hline Most frequent source of germs for healthcare infections & $111(36.8)$ \\
\hline $\begin{array}{l}\text { Hand hygiene actions that prevent transmission of germs to the patients } \\
\text { Before touching a patient } \\
\text { After a risk of body fluid exposure } \\
\text { After exposure to the immediate patients surrounding } \\
\text { Before aseptic procedure }\end{array}$ & $\begin{array}{l}233(77.2) \\
168(55.6) \\
154(51.0) \\
186(61.6)\end{array}$ \\
\hline $\begin{array}{l}\text { Hand hygiene actions that prevent transmission of germs to the healthcare workers } \\
\text { After touching a patient } \\
\text { Immediately after a risk of body fluid exposure } \\
\text { Immediately before clean aseptic procedure } \\
\text { After exposure to immediate patient surrounding }\end{array}$ & $\begin{array}{l}217(71.9) \\
176(58.3) \\
141(46.7) \\
187(61.9)\end{array}$ \\
\hline $\begin{array}{l}\text { True statement on alcohol based hand rub and hand washing with soap and water } \\
\text { Hand rubbing is more rapid for hand cleansing than hand washing } \\
\text { Hand rubbing cause skin dryness more than hand washing } \\
\text { Hand rubbing is more effective against germ than hand washing } \\
\text { Hand rubbing and hand washing are recommended to be performed in sequence } \\
\text { Time needed for alcohol based hand rub to kill germs }\end{array}$ & $\begin{array}{l}210(69.5) \\
106(35.1) \\
174(57.6) \\
85(28.2) \\
77(25.5)\end{array}$ \\
\hline $\begin{array}{l}\text { Type of hand hygiene required in the following situation } \\
\text { Before palpation of abdomen } \\
\text { Before giving an injection } \\
\text { After emptying a bed } \\
\text { After removing a glove } \\
\text { After making a patient bed } \\
\text { After visible exposure to blood }\end{array}$ & $\begin{array}{l}211(69.9) \\
149(49.3) \\
64(21.2) \\
114(37.8) \\
88(29.1) \\
232(76.8)\end{array}$ \\
\hline $\begin{array}{l}\text { What to avoid because of increased likelihood of colonization by microbes } \\
\text { Wearing jewelries } \\
\text { Damaged skin } \\
\text { Artificial finger nails } \\
\text { Regular use of hand cream }\end{array}$ & $\begin{array}{l}190(62.9) \\
223(73.8) \\
219(72.5) \\
102(33.8)\end{array}$ \\
\hline
\end{tabular}

Table 3. Respondents correct responses to practice items.

\begin{tabular}{|c|c|}
\hline Practice items & $\mathrm{n}=302(\%)$ \\
\hline Adhering to correct hand hygiene all the time & $252(83.4)$ \\
\hline Busy schedule and hand hygiene. & $105(34.8)$ \\
\hline Forgotten hand hygiene action. & $151(50.0)$ \\
\hline Hand hygiene in emergency situations & $174(57.6)$ \\
\hline Wearing gloves and hand hygiene & $216(71.5)$ \\
\hline Action when a colleague forgets to observe hand hygiene. & $255(74.5)$ \\
\hline Not reluctant to ask others to engage in hand hygiene. & $156(51.7)$ \\
\hline Newly employed staff properly instructed on hand hygiene. & $130(43.0)$ \\
\hline Feel guilty when hand hygiene is omitted. & $240(79.5)$ \\
\hline Adherence to hand hygiene is difficult in the current work set up. & $209(69.2)$ \\
\hline Hand hygiene after touching a patient & $233(77.2)$ \\
\hline Hand hygiene before touching a patient & $217(71.9)$ \\
\hline
\end{tabular}


this may likely be due to the fact that, knowledge means awareness of the consequences especially to do with the health and financial burden, with up to $78.0 \%$ found to be correctly practicing hand hygiene.

The finding of knowledge and practices of hand hygiene may also be linked with the possibility of checking up for answers by the respondents since the tool used was a self-administered questionnaire, however, efforts were made to explain the need for having correct findings by this study especially in the area of appropriate intervention by the appropriate authority. Furthermore, $51.7 \%$ of the respondents in this study received formal training on hand hygiene within the last three years, though this is less than what was obtained in a study conducted in Saudi Arabia that reported more recent participation in trainings. ${ }^{16,17}$ In addition, a study conducted in Nepal, reported that up to $60.6 \%$ and $74.2 \%$ of the respondents have respectively attended hand hygiene trainings and seminars within the past 6 months. ${ }^{13}$ We reported in this study that up to $48.3 \%$ healthcare workers did not receive any training or educational intervention on hand hygiene in the last 3 years. The number of those without recent training on hand hygiene practices indicated

Table 4. Reported barriers to hand hygiene practices.

\begin{tabular}{|c|c|c|c|}
\hline & Reasons given & $n=31$ & \\
\hline & & Yes & No \\
\hline 1. & Increased workload & $138(45.7)$ & $164(54.3)$ \\
\hline 2. & Poorly located sink in the wards and clinic & $121(40.1)$ & $181(59.9)$ \\
\hline 3. & Shortage of sink & $100(33.1)$ & $201(66.9)$ \\
\hline 4. & Shortage of water & $169(56.0)$ & $133(44.0)$ \\
\hline 5. & Shortage of soap & $144(44.7)$ & $158(55.3)$ \\
\hline 6. & Shortage of alcohol based hand rub & $149(49.3)$ & $153(50.7)$ \\
\hline 7. & Lack of encouragement & $67(22.2)$ & $235(77.8)$ \\
\hline 8. & Irritation and skin dryness & $39(13.0)$ & $263(87.0)$ \\
\hline 9. & Lack of role model & $65(21.5)$ & $237(78.5)$ \\
\hline 10. & Low risk of acquiring infection from patients. & $28(9.3)$ & $274(90.7)$ \\
\hline
\end{tabular}

Table 5. Factors associated with knowledge of hand hygiene.

\begin{tabular}{|c|c|c|c|c|c|c|}
\hline Variables & Poor & $\begin{array}{l}\text { Knowledgs } \\
\text { Fair }\end{array}$ & Good & $\chi^{2}$ & p value & AOR $(95 \% \mathrm{CI})$ \\
\hline \multicolumn{7}{|l|}{ Facility } \\
\hline MMSH & $56(76.7)$ & $97(80.8)$ & $100(91.7)$ & 8.5 & $0.014^{*}$ & $2.1(1.1-3.8)$ \\
\hline HBPH & $17(23.3)$ & 23 (19.2) & $9(8.3)$ & & & \\
\hline $\begin{array}{l}\text { Department } \\
\text { Medicine } \\
\text { Paediatrics } \\
\text { Surgery }\end{array}$ & $\begin{array}{c}5(6.9) \\
23(31.5) \\
37(50.7)\end{array}$ & $\begin{array}{l}26(21.7) \\
33(27.5) \\
43(35.8)\end{array}$ & $\begin{array}{l}20(18.4) \\
45(41.3) \\
33(30.3)\end{array}$ & 15.7 & $0.015^{*}$ & $1.4(1.1-1.7)$ \\
\hline $\begin{array}{l}\text { Obstetric\&Gynecology } \\
\text { Sex } \\
\text { Male } \\
\text { Female }\end{array}$ & $\begin{array}{l}8(10.9) \\
25(34.3) \\
48(65.7)\end{array}$ & $\begin{array}{l}50(41.7) \\
70(58.3)\end{array}$ & $\begin{array}{l}41(37.6) \\
68(62.4)\end{array}$ & 1.1 & 0.58 & \\
\hline $\begin{array}{l}\text { Age group } \\
\quad<30 \\
\quad \geq 30 \\
\end{array}$ & $\begin{array}{l}36(22.4) \\
37(26.2)\end{array}$ & $\begin{array}{l}69(42.9) \\
51(36.2)\end{array}$ & $\begin{array}{l}56(34.8) \\
53(37.6)\end{array}$ & 1.5 & 0.5 & \\
\hline $\begin{array}{l}\text { Professional Cadre } \\
\text { Doctors } \\
\text { Nurses } \\
\text { Others }\end{array}$ & $\begin{array}{l}14(19.2) \\
36(49.3) \\
23(31.5)\end{array}$ & $\begin{array}{l}37(30.8) \\
57(47.5) \\
26(21.7)\end{array}$ & $\begin{array}{c}36(33) \\
29(26.6) \\
44(40.4)\end{array}$ & 17.8 & $0.001 *$ & $1.1(0.7-1.3)$ \\
\hline $\begin{array}{l}\text { Years in service } \\
\quad<10 \\
\quad \geq 10\end{array}$ & $\begin{array}{l}47(64.4) \\
26(35.6)\end{array}$ & $\begin{array}{l}92(76.7) \\
28(23.3)\end{array}$ & $\begin{array}{l}83(76.2) \\
26(23.8)\end{array}$ & 4.13 & 0.127 & $1.3(0.8-2.1)$ \\
\hline $\begin{array}{l}\text { Training in the last } 3 \text { yea } \\
\text { Yes } \\
\text { No }\end{array}$ & $\begin{array}{l}30(41.1) \\
43(58.9)\end{array}$ & $\begin{array}{l}60(50) \\
60(50)\end{array}$ & $\begin{array}{l}66(60.6) \\
43(39.5)\end{array}$ & 6.8 & $0.033^{*}$ & \\
\hline
\end{tabular}

AOR: Adjusted Odds Ratio; *Statistically Significant; Blank cells: not qualified for inclusion in regression mode.

the need by relevant stakeholders to ensure that hand hygiene training is done periodically as this might reduce the hospital budget that can be due to consequences of hospital acquired infections resulting in poor hand hygiene. This could be due to limited information among the stakeholders on the role of hand hygiene in the prevention of hospital acquired infections.

Further, other categories of health workers showed better knowledge of $40.4 \%$. The survey also found a statistically significant association between belonging to other category of healthcare workers (CHEWs, JCHEW, and CHO) and having good knowledge of hand hygiene. However, doctors were found in this study to be $90 \%$ more likely to practice good hand hygiene compared to other healthcare providers in the hospital. This may likely be due to adequate information on the role of transmission of hospital acquired infection associated with poor hand hygiene practice throughout the medical training program that is expected to be part of training of all the specialties expected to be covered before being certified as a doctor. Barriers to non-compliance with hand hygiene practice noted in this study were non-availability of water, high workload, non-availability of soap and alcohol based hand rub and these are necessary for appropriate hand hygiene practice.

Hospital staff less of than 30 years of age in this study were $70 \%$ more likely to have good hand hygiene practice than older 
Table 6. Factors associated with practices of hand hygiene.

\begin{tabular}{|c|c|c|c|c|c|}
\hline Variables & Wrong & Correct & $x^{2}$ & p value & AOR $(95 \%$ CI $)$ \\
\hline $\begin{array}{l}\text { Facility } \\
\text { MMSH } \\
\text { HBPH }\end{array}$ & $\begin{array}{l}56(22.1) \\
10(20.4)\end{array}$ & $\begin{array}{c}197(77.9) \\
39(79.6)\end{array}$ & 0.072 & 0.8 & \\
\hline $\begin{array}{l}\text { Department } \\
\text { Medicine } \\
\text { Paediatrics } \\
\text { Surgery } \\
\text { O\&G } \\
\text { Sex } \\
\text { Male } \\
\text { Female }\end{array}$ & $\begin{array}{c}8(15.7) \\
24(23.8) \\
23(20.4) \\
11(29.7) \\
14(12.1) \\
52(28.0)\end{array}$ & $\begin{array}{l}43(84.3) \\
77(76.2) \\
90(79.6) \\
26(70.3) \\
\\
102(87.9) \\
134(72.0)\end{array}$ & 2.8 & $0.001^{*}$ & $0.4(0.2-0.7)$ \\
\hline $\begin{array}{r}\text { Age group } \\
<30 \\
\geq 30\end{array}$ & $\begin{array}{c}29(18) \\
37(26.2)\end{array}$ & $\begin{array}{c}132(82) \\
104(37.8)\end{array}$ & 3.0 & 0.08 & $0.7(0.4-1.20$ \\
\hline $\begin{array}{c}\text { Professional Cadre } \\
\text { Doctors } \\
\text { Nurses } \\
\text { Others } \\
\end{array}$ & $\begin{array}{l}14(16.1) \\
28(23.0) \\
24(25.8)\end{array}$ & $\begin{array}{l}73(83.9) \\
94(77.0) \\
69(74.2)\end{array}$ & 2.6 & 0.3 & $0.9(0.6-1.3)$ \\
\hline $\begin{array}{c}\text { Years in service } \\
1-10 \\
>10\end{array}$ & $\begin{array}{l}45(20.3) \\
21(26.3)\end{array}$ & $\begin{array}{c}177(79.7) \\
59(73.8)\end{array}$ & 1.2 & 0.3 & \\
\hline $\begin{array}{l}\text { Training in the last } 3 \text { years } \\
\text { Yes } \\
\text { No }\end{array}$ & $\begin{array}{l}37(23.7) \\
29(19.9)\end{array}$ & $\begin{array}{l}119(76.3) \\
117(80.1)\end{array}$ & 0.7 & 0.4 & \\
\hline $\begin{array}{l}\text { Knowledge } \\
\text { Poor } \\
\text { Fair } \\
\text { Good }\end{array}$ & $\begin{array}{l}22(33.3) \\
22(33.3) \\
22(33.4)\end{array}$ & $\begin{array}{l}51(21.6) \\
98(41.5) \\
87(36.9)\end{array}$ & 3.98 & 0.1 & $1.3(0.9-1.9)$ \\
\hline
\end{tabular}

AOR: Adjusted Odds Ratio; * Statistically Significant; Blank cells: not qualified for inclusion in regression mode.

healthcare workers. In addition, better hand hygiene knowledge of $76.2 \%$ was found among those less than 10 years in service compared with $23.8 \%$ for those older than 10 years in service which may be due to the ability of the younger ones to remember the necessary hand hygiene information they learnt in school. More so, $56.5 \%$ of healthcare workers attended training on hand hygiene surprisingly; exposure to training did not translate to their good hand hygiene practices. In addition, up to $80.1 \%$ of those not trained had good hand hygiene practices. This may not be unconnected with the fact that some respondents $67.3 \%$ interviewed in HBPH were employed in the last 10 years prior to this study. Coincidently, this is the period hand hygiene was gaining momentum in our hospitals, it was likely incorporated into our curriculum, and therefore they are more likely to remember and practice hand hygiene from information they learnt in school.

\section{Conclusions and \\ Recommendations}

The study found the proportion of respondents with good knowledge and practice of hand hygiene to be $36.1 \%$ and $78.0 \%$ respectively. Non-availability of materials needed to observe hand hygiene, high patients load, and inadequate water supply, including limited hand hygiene training were some of the barriers identified to negatively affect compliance with recommended hand hygiene practice. Therefore, government should ensure that these identified barriers to hand hygiene practice are addressed. Periodic assessment of compliance to recommended hand hygiene practices should be regularly conducted. Departments and individuals should be graded, those with good scores be recognized to motivate others.

\section{References}

1. Ontario Agency for Health Protection and Promotion (Public Health Ontario), Provincial Infectious Diseases Advisory Committee. Best Practices for Hand Hygiene in All Health Care Settings. 4th ed. Toronto, ON: Queen's Printer for Ontario; January 2014. 1-84 pp.

2. World Health Organization. Safe management of wastes from health care activities. Bull WHO 2001;79:171.

3. Zil-E-Ali A, Cheema MA, Wajih Ullah $M$, et al. A Survey of Handwashing Knowledge and Attitudes among the Healthcare Professionals in Lahore, Pakistan. Cureus 2017;9. Accessed on 18th November, 2017. Available from: http://www.cureus.com/articles/6283-asurvey-of-handwashing-knowledgeand-attitudes-among-the-healthcareprofessionals-in-lahore-pakistan

4. World Health Organization. Improved Hand Hygiene to Prevent Health CareAssociated Infections. Patient Saf Solut 2007;1:1-4.

5. World Health Organisation. WHO Guidelines on Hand Hygiene in Health Care: First Global Patient Safety Challenge Clean Care Is Safer Care. 2009;30. Accessed on 10th December, 2017. Available from: http://whqlibdoc.who.int/publications/2009/9789241 597906 eng.pdf

6. Vincent JL. International Study of the Prevalence and Outcomes of Infection in Intensive Care Units. JAMA 2009;302:2323.

7. Ling ML, Apisarnthanarak A, Madriaga G. The burden of healthcare-associated infections in southeast Asia: A system- 
atic literature review and meta-analysis. Clin Infect Dis 2015;60:1690-9.

8. Shobowale EO, Onyedibe KI, Adegunle KB, Elikwu CJ. An Observational and Trend Analysis Study of Hand Hygiene Practices of Healthcare Workers at A Private Nigerian Tertiary Hospital. Ann Med Health Sci Res 2017;7:84-9

9. Abdulsalam M, Ibrahim A, Michael G, Mijinyawa A. Hand washing practices and techniques among health professionals in a tertiary hospital in Kano. J Med Invest Pract 2015;10:8-12.

10. Ekwere TA, Okafor IP. Hand hygiene knowledge and practices among healthcare providers in a tertiary hospital, south west, Nigeria. Int J Infect Control 2013;9:1-10.
11. Joint Commission Mission. Hygiene Adherence: Measuring hand hygiene adherence: Overcoming the challenges. 2009: pp. 1-204.

12. Timothy A, Ekwere IPO. Hand hygiene knowledge and practices among healthcare providers in a tertiary hospital. Int J Infect Control 2013;9:1-10.

13. Khanal G, Thapa S. Awareness of hand hygiene among health care workers of chitwan, Nepal. SAGE Open 2017;7:17.

14. Ango U, Awosan K, Adamu H, et al. Knowledge, Attitude and Practice of Hand Hygiene among Healthcare Providers in Semi-urban Communities of Sokoto State, Nigeria. Int J Trop Dis Heal 2017;26:1-9.
15. Sai MSS, Rao MSS, Sandeepthi M, et al. Hand hygiene practices among health providers working in tertiary care hospitals in and around Hyderabad, Telangana State, South India. Int J Res Med Sci 2015;3:250-5.

16. Aledeilah RD. Assessment of Knowledge, Attitude and Practice of Hand Hygiene among Health Care Workers in Arar City, Saudi Arabia. Egypt J Hosp Med 2018;70:491-8.

17. AlSofiani AM, AlOmari F, AlQarny M. Knowledge and practice of hand hygiene among healthcare workers at Armed Forces Military Hospitals, Taif, Saudi Arabia. Int J Med Sci Public Health 2016:5;1282-91. 